\title{
Pengalaman Penderita Hipertensi MengkonsumsiTeh Roselladi UresosPucang Gading Semarang
}

\author{
Yunani ${ }^{1}$, Arista Adityasari $\mathbf{P}^{2}$, M. Jamaluddin ${ }^{3}$ \\ Dosen Keperawatan STIKes Karya Husada Semarang \\ E-mail:yunani.sururi@yahoo.com; aristaputri@gmail.com; afwani_80@yahoo.com
}

\begin{abstract}
ABSTRAK
Hipertensi merupakan tekanan darah persisten dimana tekanan sistoliknya diatas $140 \mathrm{mmHg}$ dan tekanan diastolinya diatas $90 \mathrm{mmHg}$. Hipertensi pada populasi lansia didefinisikan sebagai tekanan sistolik $160 \mathrm{mmHg}$ dan tekanan diastolic $90 \mathrm{mmHg}$. . Salah satu pengobatan non farmakologis yang telah dilakukan lansia adalah dengan mengkonsumsi teh rosella. Banyak studi yang memperlihatkan efektifitas rosella pada berbagai organ. Hal ini dikarenakan efek anti radikal yang dimiliki oleh kandungan rosella didalamnya mampu mengurangi radikal bebas yang terbentuk dalam aliran darah. Tujuan penelitian untuk mengeksplorasi pengalaman penderita hipertensi mengkonsumsiteh rosella sebagai terapi. Metode penelitian menggunakan desain penelitian kualitatif dengan pendekatan Fenomenologi. Partisipan pada penelitian ini adalah lansia penderita hipertensidi URESOS Pucang Gading Semarang. Hasil penelitian didapatkan sebagian besar partisipan merasakan keluhan hipertensi seperti : pusing, kaku pada leher, sulit tidur dan badan sempoyongan. Pengalaman mengkonsumsi teh rosella didapatkan sebagian besar partisipan mengalami penurunan/berkurangngya keluhan hipertensi.
\end{abstract}

Kata Kunci: Pengalaman; Rosella; Hipertensi

\section{ABSTRACT \\ Experience of Hypertension Patients Consume Rosella Tea at Uresos Pucang Gading Semarang}

Hypertension is a persistent blood pressure where the systolic pressure is above $140 \mathrm{mmHg}$ and the diastolic pressure is above $90 \mathrm{mmHg}$. Hypertension in the elderly population is defined as $160 \mathrm{mmHg}$ systolic pressure and diastolic pressure of $90 \mathrm{mmHg}$. . One of the non-pharmacological treatments that the elderly have done is to consume rosella tea. Many studies show the effectiveness of rosella in various organs. This is because the anti-radical effect possessed by the content of rosella in it is able to reduce the free radicals that are formed in the bloodstream. The purpose of the study to explore the experience of hypertensive patients consuming roselle tea as therapy. The research method used qualitative research design with Phenomenology approach. Participants in this study were elderly people with hypertension in URESOS Pucang Gading Semarang. The results obtained most of the participants felt hypertensive complaints such as: dizziness, stiffness in the neck, difficulty sleeping and body stagger. The experience of consuming Rosella tea was found that most of the participants had decreased / decreased hypertension complaints.

Keywords: Experience; Rosella; Hypertension

Jurnal SMART Keperawatan Sekolah Tinggi Ilmu Kesehatan (STIKes) Karya Husada Semarang 


\section{Pendahuluan}

Rosella (Hibiscus sabdariffa) merupakan salah satu tanaman herbal yang bermanfaat mencegah penyakit kanker, melancarkan tekanan darah, dan melancarkan buang air besar. Bagian dari bunga rosella ini yang digunakan dan bermanfaat yaitu kelopak bunga rosella. Rosella telah digunakan secara luas di banyak Negara sebagai minuman dan sumber pengobatan. Beberapa pengobatan herbal menggunakan ekstrak tanaman ini untuk diuretic, gangguan pencernaan, agen antioksidan dan hiperkolesterolemia (Yunariski, 2012).Penelitian oleh Andika, Rompas, Mulyadi (2014) yang telah meneliti tentang Pengaruh Pemberian Bunga Rosella Terhadap Perubahan Tekanan Darah Penderita Hipertensi Dengan Terapi Captopril Di Desa Kamiwangi Kecamatan Toili Barat Kabupaten Luwuk Banggai. Hasil yang diperoleh dari penelitian membuktikan adanya perbedaan tekanan darah sebelum dan sesudah diberikan bunga rosella yang menunjukkan terjadinya penurunan tekanan darah setelah penderita hipertensi mendapatkan terapi captopril kemudian diberikan bunga rosella yang di ukur kembali setelah 2 jam pemberian, masing-masing penurunan rata-rata tekanan darah sistolik maupun diastolik ialah sebesar 19,333 $\mathrm{mmHg}$ dan 10,00 mmHg. Sedangkan pada kelompok kontrol yang hanya di berikan terapi captopril saja, mendapatkan penurunan tekanan sistolik $9,00 \mathrm{mmHg}$ dan diastolik 4,33 $\mathrm{mmHg}$ dalam 2 jam pemberian.

Bagian dari bunga rosella ini yang digunakan dan bermanfaat yaitu kelopak bungga rosella. Rosella telah digunakan secara luas di banyak negara sebagai minuman dan sumber pengobatan. Beberapa pengobatan herbal menggunakan ekstrak tanaman ini untuk diuretik, gangguan pencernaan, agen antioksidan, dan hiperkolesterolemia(Andika, Rompas, dan Mulyadi, 2014).Kelopak rosella mengandung antioksidan yang dapat menghambat terakumulasinya radikal bebas. Selain itu rosella juga berkhasiat untuk menurunkan asam urat, Hipertensi, Diabetes melitus, memperbaiki metabolisme tubuh, menghambat sel kanker, mencegah sariawan dan panas dalam, menambah vitalitas, meredakan batuk, mencegah flu, anti hipertensi, anti kanker, anti depresi, antibiotik, aprodisiak, diuretik (peluruh kencing), sedatif, tonik, dan menurunkan absorpsi alkohol (Kurniasih, 2014).Pengalaman adalahsesuatu yang pernah dialami (dijalani, dirasai, ditanggung) baik yang sudah lama atau baru saja terjadi (KBBI, 2005).

Rumusan masalah dalam penelitian ini yaitu "Bagaimanakah pengalaman penderita hipertensi mengkonsumsiteh rosella?". Tujuan penelitian ini adalah untuk mengeksplorasi pengalaman penderita hipertensi mengkonsumsiteh rosella. 


\section{Tinjauan Teoritis}

Pengalaman adalahsesuatu yang pernah dialami (dijalani, dirasai, ditanggung) baik yang sudah lama atau baru saja terjadi (KBBI, 2005). Pengalaman sebagai sumber pengetahuan adalah suatu cara untuk memperoleh kebenaran pengetahuan dengan cara mengulang kembali pengetahuan yang diperoleh dalam memecahkan masalah yang dihadapi masa lalu. Pengalaman dapat mengembangkan kemampuan mengambil keputusan yang merupakan manifestasi dari keterpaduan menalar secara ilmiah dan etik yang bertolak dari masalah nyata dalam bidang kerja

Rosella(Hibiscus Sabdariffa)merupakan salah satu tanaman herbal yang bermanfaat mencegah penyakit kanker, melancarkan tekanan darah, dan melancarkan buag air besar. Bagian dari bunga rosella ini yang digunakan dan bermanfaat yaitu kelopak bungga rosella. Rosella telah digunakan secara luas di banyak negara sebagai minuman dan sumber pengobatan. Beberapa pengobatan herbal menggunakan ekstrak tanaman ini untuk diuretik, gangguan pencernaan, agen antioksidan, dan hiperkolesterolemia (Andika, Rompas, dan mulyadi, 2014). Pada tahun 1576 seorang ahli botani asal belanda bernama M.de L'obel menemukan tanaman ini di tanam di halaman sebuah rumah di Pulau Jawa. Padahal rosella berasal dari India. Diduga tanaman ini di bawa oleh pedagang India saat datang ke Indonesia sekitar abad ke-14. Banyak pendapat yang mengira bahwa tanaman rosella berasal dari Afrika, memang rosella banyak tumbuh disana dan dibawa oleh para budak Afrika hingga ke berbagai belahan dunia, antara lain, Sudan, Mexico, Jamaika, Brasil, Panama, serta di berbagai Negara bagian Amerika dan Australia. Namun, sebenarnya tanaman ini berasal dari India bagian barat (Kurniasih, 2014).

Tanaman rosella dapat tumbuh didaerah tropis dan sub tropis yang hangat (25-300C) namun cukup lembab (70\%). Rosella cocok di tanam pada ketinggian 0-1.000 m di atas permukaan laut, dengan curah hujan 140-270 mm per bulan. Pada curah hujan rendah rosella masih dapat tumbuh, tetapi tidak sebaik di daerah bercurah hujan tinggi. Agar tanaman ini dapat tumbuh maksimal di butuhkan air dan sinar matahari penuh selama 12 jam untuk pembungaan dan berbuah. Umumnya rosella dapat tumbuh pada semua jenis selama tanah tersebut kaya akan humus, gembur, dan memiliki drainase yang baik dengan $\mathrm{pH}$ 6,5-7,5 (Widyanto dan Anne, 2009). Kelopak bunga rosella mengandung vitamin C (260-280 mg setiap $100 \mathrm{~g}$ ), vitamin D, vitamin B1, vitamin B2, niacin riboflavin, betakaroten, zat besi, asam amino, polisakarida, omega 3, kalsium, dan lain-lain.rasa asam dari kelopak bunga itu disebabkan kandungan vitamin $\mathrm{C}$, 
asam sitrat, dan asam glikolik. Daun dan buah rosella juga mengandung senyawa bermanfaat, diantaranya saponin, flavoid dan politenol. Kandungan gizi kelopak bunga segar tiap 100 gram yaitu, protein 1,145 gr, lemak 2,61 gr, serat 12 gr, kalsium 1,263 gr, fosfor 273,2 mg, zat besi $8,98 \mathrm{mg}$, malic acid 3,31 \%, fruktosa $0,82 \%$, sukrosa $0,24 \%$, karotin 0,029 \%, tiamin 0,117 $\mathrm{mg}$, niasin 3,765 mg, vitamin C 244,4 mg (Kurniasih 2014).

Kelopak rosella mengandung antioksidan yang dapat menghambat terakumulasinya radikal bebas. Selain itu rosella juga berkhasiat untuk menurunkan asam urat, Hipertensi, Diabetes melitus, memperbaiki metabolisme tubuh, menghambat sel kanker, mencegah sariawan dan panas dalam, menambah vitalitas, meredakan batuk, mencegah flu, anti hipertensi, anti kanker, anti depresi, antibiotik, aprodisiak, diuretik (peluruh kencing), sedatif, tonik, dan menurunkan absorpsi alkohol (Kurniasih, 2014).

Hipertensi merupakan tekanan darah persisten dimana tekanan sistoliknya diatas 140 $\mathrm{mmHg}$ dan tekanan diastolinya diatas $90 \mathrm{mmHg}$. Hipertensi pada populasi manula, didefinisikan sebagai tekanan sistolik $160 \mathrm{mmHg}$ dan tekanan diastolic $90 \mathrm{mmHg}$. Hipertensi merupakan penyebab utama gagal jantung, stroke dan aggal ginjal (Brunner \& Suddart, 2001). Faktor risiko hipertensi dekelompokkan menjadi factor risiko yang tidak dapat dikontrol seperti : jenis kelamin, umur dan keturunan (genetic). Faktor risiko terjadinya hipertensi yang dapat dikontrol meliputi : obesitas, kurang olahraga, kebiasaan merokok, konsumsi garam berlebih, minum alcohol, minum kopi dan stress. Penatalaksanaan hipertensi meliputi : penatalaksanaan farmakologi dan non garmakologi.

\section{Metode Penelitian}

Desain penelitianmenggunakan desainpenelitian kualitatif dengan pendekatan fenomenologi. Penelitian ini bertujuan mengeksplorasi pengalaman penderita hipertensi selama mengkonsumsi terapi teh rosella sebagai terapi hipertensi.Penelitian dilakukan di Uresos Pucang Gading Semarang pada bulan Agustus 2016-Februari 2017.Partisipanpenelitian ini adalah lansia penderita hipertensi di URESOS Pucang Gading Semarang. Adapun kriteria inklusi partisipan pada penelitian ini adalah sebagai berikut : bersedia menjadi partisipan, lansia Penderita hipertensi yang masih aktif, umur partisipan 60 - 75 tahun, partisipan pernah/sedang mengkonsumsi teh rosella, tidak memiliki gangguan pendengaran, mampu berkomunikasi aktif. 
Sedangkankriteria eksklusi : memiliki penyakit penyerta seperti Gagal ginjal, Gagal jantung dan Diabetes Mellitusdan partisipan yang sedang sakit

Teknik pengambilan partisipan dilakukan dengan cara purposive sampling, dimana peneliti mengambil partisipan sesuai dengan kriteria yang telah ditentukan oleh peneliti. Jumlah partisipan pada penelitian ini sebanyak 4 partisipan. Instrumen utama penelitian yang digunakan dalam penelitian ini adalah peneliti sendiri. Instrumen penelitian pendukung lainnya adalah alat perekam, alat tulis dan panduan wawancara semi terstruktur yang dibuat sendiri oleh peneliti yang digunakan untuk mengumpulkan data. Uji keabsahan pada penelitian dengan melakukan triangulasi sumber yaitu dengan pengelola Uresos dan triangulasi teori.

Teknik pengambilan data dilakukan dengan melakukan Indepth interview/wawancara partisipan dengan melakukan perekaman hasil wawancara serta melakukan observasi pada partisipan untuk mendapatkan field note/catatatan lapangan. Analisa data penelitian ini dilakukan melalui tahapan sebagai berikut : peneliti membuat transkrip hasil wawancara indepth interview dengan partisipan, Membaca transkrip berulang kali untuk menentukan kata kunci hasil penelitian, peneliti melakukan pengkategorian data penelitian berdasarkan kata kunci, peneliti menentukan tema penelitian

\section{Hasil Penelitian}

Data penelitian yang didapatkan dengan melakukan wawancara mendalam/indepth interview terhadap penderita hipertensi yang mengkonsumsi teh rosella adalah sebagai berikut :

1. Mengeksplor Keluhan Hipertensi

Hasil wawancara keluhan yang dirasakan partisipan saat tekanan darah meningkat didapatkan beberapa keluhan sebagai berikut :

a. Pusing

Hasil penelitian didapatkan sebagian besar partisipan penderita hipertensi mengalami pusing (nyeri kepala) saat tekanan darahnya tinggi, hal tersebut sesuai dengan kutipan wawancara sebagai berikut :

"Pusing tiba-tiba, bangun tidur tiba-tiba pusing,..." (P1)

"Pusing dibagian depan kepala, .... Ya rasanya berat..” (P2)

“...pusing..” (P4)

b. Badan sempoyongan 
Hasil wawancara dari penelitian juga didapatkan sebagian besar partisipan menyatakan badan sempoyongan saat tekanan darah naik, hal ini sesuai dengan kutipan pernyataan partisipan berikut :

“Kalau mau jalan rasane (rasanya) mau jatuh...”(P1)

"Ya kalau buat jalan sempoyongan gitu,..”(P2)

“Badan gliyer-gliyer (sempoyongan) (P4)

c. Kaku dileher

Hasil wawancara dari penelitian didapatkan sebagian besar partisipan menyatakan kaku pada leher saat tekanan darah naik, hal ini sesuai dengan kutipan pernyataan partisipan berikut :

"Sebelah tengkuk (leher) chengeng-chengeng (sakit)...”(P1)

"Kaku dileher itu mbak,...(P2)

"Kaku,... Kenceng-kenceng (kencang) dileher..." (P4)

d. Sulit tidur

Hasil wawancara dari penelitian didapatkan sebagian besar partisipan menyatakan mengalami sulit tidur saat tekanan darah meningkat, hal ini sesuai dengan kutipan pernyataan partisipan berikut :

"Tidak bisa tidur.." (P1)

"Sering terbangun, tidur juga sulit..." (P2)

"Sering bangun tiba-tiba, ...tidur gak bisa ampleng (nyenyak)..." (P4)

2. Pengalaman mengkonsumsi hipertensi

Hasil wawancara terhadap pengalaman mengkonsumsi teh rosella didapatkan sebagian besar partisipan mengalami penurunan keluhan hipertensi atau mengurangi keluhan hipertensti.

Hasil ini diperkuat oleh pernyataan partisipan sesuai dengan kutipan berikut :

"Ya..ada perubahan, tensi turun,..." (P2)

"Ya .. enak aja,...jadi seger,....(P3)

"Badan saya lebih entheng (ringam) juga...”(P4)

Selain itu sebagian partisipan juga mengalami penurunan nyeri kepala (pusing) sesuai dengan kutipan berikut :

"Sekarang gak pernah pusing,...” (P2)

"Pusing saya juga sudah berkurang,..." (P4) 
Penurunan keluhan hipertensi lainnya juga dirasakan oleh sebagian partisipan yaitu leher tidak kaku lagi, hal ini sesuai dengan pernyataan partisipan sebagai berikut :

“Lehernya terasa enteng (ringan),...” (P2)

"Badannya gak kaku-kaku lagi,...” (P4)

Sebagian partisipan juga menyatakan badannya lebih sehat dan tidak sempoyongan lagi sesuai dengan kutipan sebagai berikut :

“Gak sempoyongan,....” (P2)

"badan jadi seger.. " $(P 3)$

“Badan lebih enteng(ringan),...” (P4)

\section{Pembahasan}

a. Mengeksplor Keluhan Hipertensi

Hasil wawancara keluhan yang dirasakan partisipan saat tekanan darah meningkat didapatkan beberapa keluhan seperti pusing, badan sempoyongan, kaku dileher, sulit tidur. Keluhan tersebut sesuai dengan hasil wawancara dari sumber triangulasi yang menyatakan bahwa keluahan yang dirasakan oleh penderita hipertensi saat melakukan pemeriksaan di klinik antara lain : pusing, kaku pada leher, badan sempoyongan.Hasil penelitian ini juga sesuai dengan teori Rohkaeni, 2001 yang menunjukkan manisfestasi hipertensi seperti mengeluh sakit kepala/pusing, lemas dan kelelahan. Hal ini bisa terjadi karena sistem saraf simpatis merangsang pembuluh darah yang mengakibatkan tambahan aktifitas vasokonstriksi. Vasokonstriksi mengakibatkan aliran penurunan aliran darah ke ginjal, menyebabkan pelepasan rennin. Renin merangsang pembentukan angiotensin I yang kemudian diubahn menjadi angotensin II yang akan merangsang sekresi aldosteron oleh kortek adrenal. Hormon ini menyebabkan retensi natrium dan air oleh tubulus ginjal menyebabkan peningkatan volume intra vaskuler dan meningkatkan peningaktan tekanan darah.

b. Pengalaman mengkonsumsi hipertensi

Hasil wawancara terhadap pengalaman mengkonsumsi teh rosella didapatkan sebagian besar partisipan mengalami penurunan keluhan hipertensi atau mengurangi keluhan hipertensti sepertipenurunan nyeri kepala (pusing), leher tidak, badannya lebih sehat dan tidak sempoyongan. 
Hasil wawancara tersebut sesuai dengan pernyataan triangulasi yang menyatakan mereka mengkonsumsi teh rosella. Semua partisipan pada penelitian ini mengatakan mengalami berkurangnya keluhan hipertensi seperti pusing, kaku tengkuk dan susah tidur. Hal ini didukung oleh penelitian Gavrila, yang menunjukkan ada pengaruh pemberian rosella terhadap penurunan tekanan darah sistolik. Penurunan tekanan darah ini dapat diikuti dengan berkurangnya keluhan tanda dan gejala hipertensi seperti pusing, kaku tengkuk dan kesulitan tidur. Senyawa antosianin dan proantosianidin yang terdapat pada rosella (hibiscus sabdariffa) diduga menjadi senyawa biokatif yang bertangunggung jawab dalam menurunan tekanan arah. Senyawa tersebut juga diduga member efek antihipertensidari antosianin melalui penghambatan ACE II dank arena efek vasodilatasi.

\section{Kesimpulan}

Keluhan hipertensi pada partisipan penelitian sebagain besar partisipan mengatakan pusing, kaku kuduk, badan tidak enak dan keesulitan tidur.Pengalaman penderita hipertensi mengkonsumsi teh rosella didapatkan bahwa semua partisipan mengatakan mengalami penurunan keluhan hipertensi seperti berkurangnya pusing, kaku kuduk dan badan lebih sehat.

\section{Saran}

Uresos hendaknya dapat melakukan pemantauan keluhan hipertensi pada partisipan secara berkala melalui pemeriksaan tekanan darah rutin pada partisipan.Selain itu partisipandapatmengkonsumsi teh rosella sebagai terapi herbal dan digunakan sebagai terapi alternative untuk menurunkan tekanan darah atau keluhan akibat hipertensi

\section{Daftar Pustaka}

Andika, I., Rompas, S., \&Mulyadi, N. (2014). Pengaruh Pemberian Bunga Rosella Terhadap Perubahan Tekanan Darah Penderita Hipertensi Dengan Terapi Captopril Di Desa Kamiwangi Kecamatan Toili Barat Kabupaten Luwuk Banggai. Jurnal Keperawatan, 2(2). http://ejournal.unsrat.ac.id/index.php/jkp/article/view/5270/4783

Black, J.M., \& Hawk, J.H. (2005). Medical Surgical Nursing Clinical Management for Positive Outcomes. $\left(7^{\text {th }}\right.$ Ed), St. Louis, Missouri : Elsevier Saunders.

Fikri. 2008. Mentimun, Murah dan Menyegarkan. Tabloid Cempaka

Guyton, A.C., \& Hall, J.E. (2008). Fisiologi Kedokteran. Edisi 11, Alih bahasa : Irawati et al. Jakarta : Penerbit Buku Kedokteran EGC.

Ignativius, D.D., \& Workman, M.L. (2006). Medical-Surgical Nursing : Critical Thingking For Collaborative Care. $\left(4^{\text {th }}\right.$ Ed), St. Louis, Missouri : Elsevier Saunders.

Kurniasih. 2014. Budidaya Mahkota Dewa \& Rosella. Yogyakarta. Pustaka Baru Press. 
Kusumastuti, I. R. (2014). Roselle (Hibiscus Sabdariffa Linn) Effects On Lowering Blood Pressure As A Treatment For Hypertension. Majority, 3(07). http://juke.kedokteran.unila.ac.id/index.php/majority/article/view/480

Smeltzer, S.C., Bare, B.G., Hinkle, J.L., \& Cheever, K.H. (2008). Brunner \& Suddarth's Textbook of Medical-Surgical Nursing. $\left(11^{\text {th }}\right.$ Ed), Philadelphia : Lippincott Williams \& Wilkins

Sudoyo, A.W., Setiyohadi, B., Alwi I., Simadibrata, M., \& Setiati, S., et al. (2006). Buku Ajar Ilmu Penyakit Dalam. Edisi 4, Jakarta : FKUI.

Juanedi. E. 2013. Hipertensi Kandas Berkat Herbal. Jakarta : Fmedia. 